J. Lake Sci. (湖泊科学), 2017, 29(3): 604-616

DOI 10. 18307/2017. 0309

(c) 2017 by Journal of Lake Sciences

\title{
换水率和营养水平对太湖流域横山水库硅藻水华的影响”
}

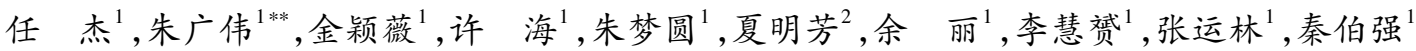 \\ (1: 中国科学院南京地理与湖泊研究所湖泊与环境国家重点实验室,南京 210008) \\ (2: 江苏省太湖水污染防治办公室, 南京 210013)
}

\begin{abstract}
摘 要: 为探讨水文过程对水库硅藻异常增殖的影响, 对江苏宜兴横山水库的硅藻生消过程中浮游植物、水质、降水、水 位、气温等指标进行观测研究. 结果表明, 横山水库硅藻年际生物量波动很大, 9 月出现明显的异常增殖, 总生物量达到 $14.27 \mathrm{mg} / \mathrm{L}$, 硅藻的优势属为针杆藻 (Synedra) 、小环藻 (Cyclotella) 、曲壳藻 (Achnanthes) 和直链藻 (Melosira), 以针杆藻的 优势度最高; 浮游植物生物量与营养盐浓度关系不明显, 与总氮浓度甚至呈负相关, 但小环藻生物量与水体溶解性磷浓 度呈正相关; 水库的换水率与浮游植物生物量、硅藻的异常增殖过程和营养盐浓度水平均密切关联, 总氮、溶解性磷浓度 与水库换水率呈正相关, 而硅藻生物量与水库换水率呈指数负相关. 数值拟合分析显示硅藻生物量可以用换水率和磷浓 度推算而得. 研究表明, 对于中营养水平的水库, 硅藻生物量变化可能受水文过程与水质条件共同控制, 在水库的硅藻水 华防控中, 既要加强营养盐水平的严格控制, 也需考虑水文过程的调控手段.
\end{abstract}

关键词: 硅藻;水华;换水率;横山水库;富营养化;太湖流域

\section{Combined effects of water exchange rate and nutrient on diatom proliferation in Hengshan Reservoir, Taihu Basin}

REN Jie $^{1}$, ZHU Guangwei ${ }^{1 * *}$, JIN Yingwei ${ }^{1}$, XU Hai ${ }^{1}$, ZHU Mengyuan ${ }^{1}$, XIA Mingfang ${ }^{2}$, YU Li $^{1}$, LI Huiyun $^{1}$, ZHANG Yunlin ${ }^{1} \&$ QIN Boqiang ${ }^{1}$

(1: State Key Laboratory of Lake Science and Environment, Nanjing Institute of Geography and Limnology, Chinese Academy of Sciences, Nanjing 210008, P.R.China)

(2: Taihu Water Pollution Control Office of Jiangsu Province, Nanjing 210013, P.R. China)

\begin{abstract}
Phytoplankton, water quality and water level in Hengshan Reservoir of Taihu Basin were studied with the meteorological indexes, in order to analyze the influence of hydrological process on diatom proliferation in the reservoir. The results reveal that the annual diatom biomass shows the significant fluctuations. The diatom proliferation in September is considerably high with the biomass of $14.27 \mathrm{mg} / \mathrm{L}$. Genera of the dominant diatom are Synedra, Cyclotella, Achnanthes and Melosira, among which Synedra shows the highest abundance of dominance. Correlation of phytoplankton biomass with nutrients is weak and with the total nitrogen is even negative. Cyclotella biomass is positive related with soluble phosphorus. The water exchange rate in Hengshan Reservoir shows the strong controlling effect on algae biomass, diatom proliferation and nutrient level. Both total nitrogen and soluble phosphorus show the negative correlation with water exchange rate. The simulation analysis indicates that diatom biomass in Hengshan Reservoir is affected by the joint effects of hydrology and water quality. With the purpose of preventing and controlling diatom bloom in reservoirs, the management should pay an emphasis on both nutrient reduction and water residence time regulation.
\end{abstract}

Keywords: Diatom; bloom; water exchange rate; Hengshan Reservoir; eutrophication; Taihu Basin

近 20 年来, 我国许多湖库型的水源地都受到了富营养化问题的威胁 ${ }^{[1-2]}$. 其中太湖 2007 年水危机以影

* 科技部国际科技合作专项 (2015DFG91980,2014DFG91780)、中国科学院前沿科学重点研究项目 (QYZDJ-SSWDQC008)、国家自然科学基金项目 (41671494, 51279194) 和江苏省太湖水环境综合治理科研项目 (TH2014304) 联 合资助. 2016-07-26 收稿; 2016-09-28 收修改稿. 任杰(1991 ), 男, 硕士; E-mail: jren1991@ outlook.com.

** 通信作者;E-mail: gwzhu@ niglas.ac.cn. 
响力和危害最为典型, 突出了我国水源地水质恶化的现状 ${ }^{[3-4]}$. 对于浅水湖泊型水源地而言, 蓝藻的异常增 殖往往是最主要的威胁, 而对于水库型水源地而言, 硅藻的危害更为普遍. 如沙河水库浮游植物中, 硅藻占 全年浮游植物生物量的 $43 \%$, 而蓝藻则仅占 $22 \%{ }^{[5]}$. 任杰等对苏南 17 座水源地型水库的调查发现, 春末夏 初这些水库均是硅藻生物量占优, 超过半数的水库出现轻度硅藻水华 ${ }^{[6]}$.

对于湖库中硅藻异常增殖的影响因素, 目前主要关注营养盐、温度、光照、浮游动物牧食等, 对水文条件 的影响研究较少 ${ }^{[7-8]}$. 作为一个人工水体, 水库的水位调节幅度大、频次高, 水力停留时间短, 降雨等水文事 件对水质影响可能较大 ${ }^{[9-10]}$, 同时水库的水位波动等水文条件可能影响浮游植物组成 ${ }^{[11]}$. Rangel 等对 8 个 巴西水库的浮游植物研究表明, 水文过程和磷浓度是浮游植物生物量的主要控制因素 ${ }^{[12]}$. 但该研究并未专 门针对硅藻进行分析.

横山水库是苏南地区非常典型的饮用水源型水库, 受藻类异常增殖的困扰. 2008 年横山水库总氮 $(\mathrm{TN})$ 、总磷 $(\mathrm{TP})$ 、五日生化需氧量 $\left(\mathrm{BOD}_{5}\right)$ 等指标接近或超过地表水 $\mathrm{II}$ 类水标准, 水质指标波动很大 ${ }^{[13]}$. 蓝 藻和硅藻在浮游植物的季节演替中发挥着重要作用 ${ }^{[14]}$. 为探究该区域水库硅藻危害的影响因素, 本研究于 2015 年 4- 10 月, 对横山水库的水质、硅藻、水文变化过程进行监测, 分析水质、水文条件与硅藻生物量之间 的关系,为我国水库型水源地的有害藻类灾害防控提供科学依据.

\section{1 材料与方法}

\section{1 水库概况}

横山水库是一座大型水库, 位于江苏省宜兴市西南区、宜溧太华山区, 总库容 $11200 \times 10^{4} \mathrm{~m}^{3}$, 水面面积 $6.0 \mathrm{~km}^{2}$, 集水面积为 $154.8 \mathrm{~km}^{2[6]}$. 横山水库的主要功能是宜兴市水厂供水, 同时具有防洪、灌溉、渔业养殖 等功能. 水库流域属于亚热带低山丘陵区, 主要经济林为毛竹、茶叶和板栗 ${ }^{[15]}$, 主要农业作物为水稻、蔬菜 等. 流域内基本没有工业.

\section{2 采样点布设}

2014 年 6 月 15 日,横山水库水色异常期 间, 在库体布设 4 个采样点 ( L1 L 4 , 图 1) 以 及 2 个人湖河道采样点 $(R 1 、 R 2$, 图 1), 采集 水样进行营养盐状况及藻类状况的初步调 查. 6 月 19 日,在 L1、L4、L5 3 个采样点采集 柱状底泥样品, 分层分析底泥中氮、磷和有机 质含量.

2015 年 4 月底至 10 月底, 在水库硅藻异 常增殖易发期, 库体布设 3 个采样点 ( L2、L6、 $\mathrm{L} 3$, 图 1) 采集水样监测水质和藻类状况, 其 中 5-8 月监测频率为每 14 天一次, 其他月 份为每月一次. 监测期间样点最大水深 为 $11.8 \mathrm{~m}$.

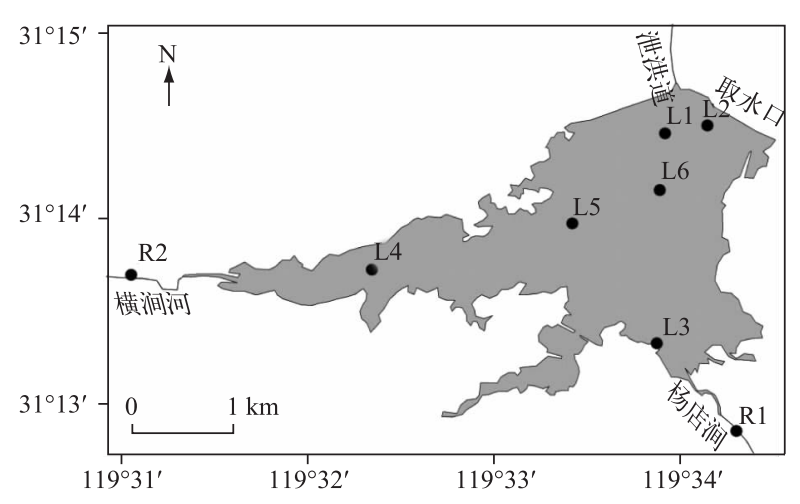

图 1 横山水库采样点分布

Fig.1 Sampling sites in Hengshan Reservoir

\section{3 监测方法}

现场监测方法参照文献 [5]. 2014 年 6 月采样时, L1 点水深为 $11.8 \mathrm{~m}$, 按照 $0.5 、 5 、 11 \mathrm{~m}$ 分 3 层采样, 其 余样点采集水下 $0.5 \mathrm{~m}$ 的表层样. 2015 年采样期间, 根据 3 个点的水深采集表 ( $0.5 \mathrm{~m})$ 、中 (水深一半)、底 (泥上 $0.5 \mathrm{~m}$ ) 3 层水样各 $1.5 \mathrm{~L}$, 用于营养盐、悬浮物等水质指标的分析, 样品混合后分别取 $1 \mathrm{~L}$ 水样用于浮 游植物固定. 现场用美国黄石仪器公司 YSI 6600V2 型多参数水质分析仪测定水温( WT)、 $\mathrm{pH}$ 、溶解氧 ( DO ) 浓度、浊度、电导率等指标, 用直径 $30 \mathrm{~cm}$ 的赛氏盘测定水体透明度 $(\mathrm{SD})$. 水样冷藏后当天带回实验室进行 过滤等预处理.

$\mathrm{TN}$ 和溶解性总氮 (DTN) 浓度分别通过碱性过硫酸钾消解、紫外分光光度法测定 (波长 $210 \mathrm{~nm}$ ); TP 和 溶解性总磷 (DTP) 浓度采用碱性过硫酸钾消解一钼锑抗显色分光光度法测定 (波长 $700 \mathrm{~nm}$ ), 其中, TN 和 TP 
浓度的测定使用原水; DTN 和 DTP 浓度的测定使用 GF/F 滤膜滤后的水样. 反应性活性磷( SRP) 浓度采用 荷兰 Skalar 流动注射分析仪测定. 叶绿素 $\mathrm{a}(\mathrm{Chl} . \mathrm{a})$ 浓度采用热乙醇提取、分光光度法测定 (波长 $665 \mathrm{~nm} 、 750$ $\mathrm{nm})$. 悬浮颗粒物 (SS) 浓度采用 Whatman $\mathrm{GF} / \mathrm{F}$ 滤膜过滤, $105^{\circ} \mathrm{C}$ 烘干重量法测定. 高锰酸盐指数 $\left(\mathrm{COD}_{\mathrm{Mn}}\right)$ 采 用高镇酸钾水浴氧化后草酸钠、高锰酸钾氧化滴定法测定 ${ }^{[16]}$.

底泥柱状样按照 $2 \mathrm{~cm}$ 分层后, 冷冻干燥, 研磨后测定有机碳 (TOC) 、TN、TP 含量. 其中 TOC 含量采用重 铬酸钾水浴氧化, 硫酸亚铁滴定法测定换算. 称取约 $0.05 \mathrm{~g}$ 沉积物稀释到 $50 \mathrm{ml}$ 纯净水中, 而后参照水体 $\mathrm{TN} 、 \mathrm{TP}$ 浓度的测定方法测定沉积物 TN $\mathrm{TP}$ 含量.

浮游植物使用 Olympus CH 生物光学显微镜镜检, 鉴定到属, 并根据体积-重量经验公式换算出生物量 (BM, mg/L), 鉴定和体积计算方法见文献 [17-18]. 某种属浮游植物优势度 $(Y)$ 的计算参照 McNaughton 在 1967 年提出的方法, 即用浮游植物某属生物量与浮游植物总生物量的比值乘以其出现频次, 当 $Y \geqslant 0.02$ 时, 则判断该属为优势属 ${ }^{[19]}$.

为获得横山水库的综合富营养化状态, 按照中国环境监测总站颁发的《湖泊 (水库) 富营养化评价方法 及分级技术规定》[总站生字 [2001] 090 号] , 根据水体 TN 浓度、TP 浓度、COD $\mathrm{Mn}_{\mathrm{n}}$ SD、Chl.a 浓度 5 个指标加 权平均计算综合营养状态指数 $(T L I)$.

\section{4 水文气象数据}

2015 年日平均降雨量、日平均气温等气象数据由位于水库西部 $12 \mathrm{~km}$ 的十思园自动气象站提供. 日平 均水位、库容曲线、雨量、面雨量等水文数据由横山水库管理处提供. 其中, 采样前 $10 \mathrm{~d}$ 的平均气温计作 $A T_{10}$, 用于分析积温效应对藻类生长的影响.

由于浮游植物对环境的响应时间约为 2 周 ${ }^{[20]}$, 为估算水库的换水率, 利用库容、降雨数据, 结合横山水 库的集水面积,估算出监测期每次采样前 $15 \mathrm{~d}$ 水库的平均换水率 $\left(W R_{15}\right)$,公式为:

$$
W R_{15}=\sum_{i=1}^{15} P_{i} \cdot S /\left(\frac{1}{15} \sum_{i=1}^{15} V_{i}\right)
$$

式中, $P_{i}$ 为第 $i$ 日面雨量 $(\mathrm{m}) ; S$ 为集水面积 $\left(\mathrm{m}^{2}\right) ; V_{i}$ 为第 $i$ 日库容 $\left(\mathrm{m}^{3}\right)$.

\section{5 统计方法}

数据图表及统计分析主要由 Excel 2016 与 R 3.2.2 软件完成 ${ }^{[21-22]}$. 主要的统计方法有相关关系、指数回 归、非线性回归、多元线性回归等方法. 在比较不同模型适宜性上, 采用最小信息准则法 (Akaike information criterion, $\mathrm{AIC}$ ) 和基于 $\mathrm{F}$ 检验的方差分析 (analysis of variance, ANOVA) 来确定拟合函数中必要的参数和拟合 方程式.

\section{2 结果}

\section{1 水文气象状况}

2014 年 6 月横山水库硅藻生物量较高期间, 表层水温平均为 $27.1^{\circ} \mathrm{C}$, 坝前 $\mathrm{L} 1$ 样点底层 $(11 \mathrm{~m})$ 水温为 $14.4^{\circ} \mathrm{C}$, 水温随深度线性下降, 在 $7 \mathrm{~m}$ 时水温低于 $20^{\circ} \mathrm{C} .2014$ 年 5 月 11 日 -6 月 20 日, 横山水库降雨很少, 只有 $58.6 \mathrm{~mm}$,干旱少雨对硅藻生物量增高可能有影响.

横山水库地区 2015 年气温最低值出现在 1 月下半月 $\left(4.8^{\circ} \mathrm{C}\right)$; 最高值出现在 8 月上半月, 为 $28.2^{\circ} \mathrm{C}$. 在 3 月上半月以前, 该地区平均气温总体低于 $8^{\circ} \mathrm{C}$, 在 3 月下半月出现幅度较大的上升, 平均气温为 $13.7^{\circ} \mathrm{C}$, 并 总体上处于不断上升的趋势, 直到 8 月达到最高值 (图 2).

自 2015 年 3 月下旬开始, 横山水库雨量明显增多, 持续到 9 月. 期间, 上半年的降雨量波动较大, 特别是 在 2、4、5 月上、下半月累积降雨量差距显著. 累积降雨量的最高峰值出现在 6 月下半月; 此外, 9 月上半月再 次出现累积降雨量峰值 (图 2), 主要为 9 月 4 日单日雨量达 $67 \mathrm{~mm}$ 的暴雨所贡献.

2015 年横山水库水位全年保持在 $31 \mathrm{~m}$ 以上. 在 1-2 月受降雨量较小和放水影响, 处于明显下降趋势 (从 1 月 1 日的 $32.8 \mathrm{~m}$ 持续降低至 2 月 27 日的 $31.5 \mathrm{~m}$ ), 在 3 月随降水量的增加水位快速上升 (从 $31.5 \mathrm{~m}$ 上 升至 4 月 8 日的 $34.3 \mathrm{~m}$ ), 随后进人较为平稳的状态, 保持在 $33.8 \sim 35.1 \mathrm{~m}$ 之间 (图 2).

\section{2 水质状况}

横山水库 2014 年 6 月各点位及 2015 年历次调查各水质指标 3 个点位 3 层水样的平均值见表 1 , 其中 


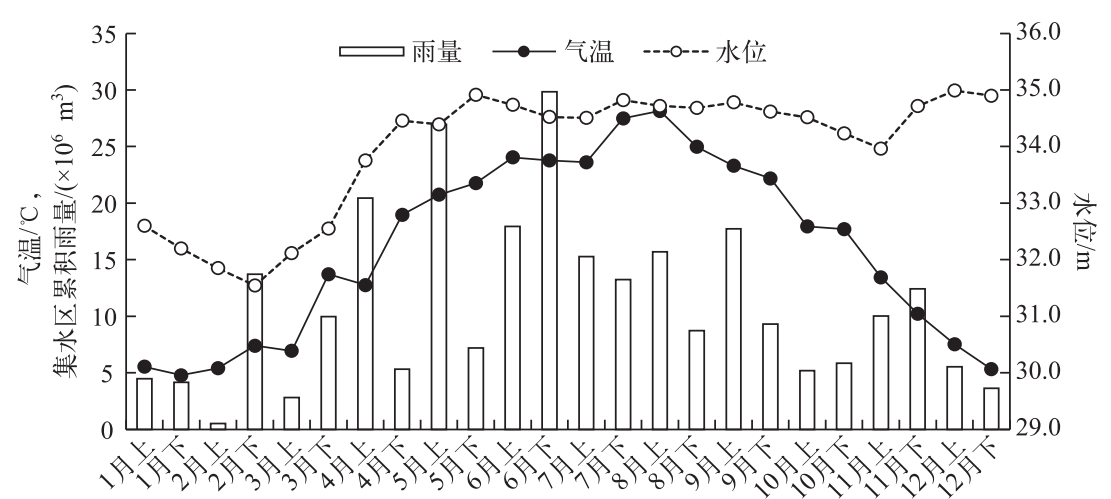

图 22015 年横山水库半月平均气温、水位和累积雨量

Fig.2 15-day average of air temperature, water level and rainfall in Hengshan Reservoir in 2015

DO 为底层溶解氧, 其浓度自 5 月中旬开始至 9 月末一直处于较低水平. WT 为表层水温, 在 8 月达到最大 值, 且在 10 月末保持着与 6 月初相当的值. TN 浓度在 5 月 19 日达到最大值, 随后处于不断下降的趋势, 从 劣 $\mathrm{V}$ 类水平降至 $\mathrm{IV}$ 类. TP 浓度在 $0.018 \sim 0.061 \mathrm{mg} / \mathrm{L}$ 之间波动, 平均浓度为 $0.030 \mathrm{mg} / \mathrm{L}$, 属 III 类水水平. $\mathrm{COD}_{\mathrm{Mn}}$ 介于 $1.61 \sim 2.60 \mathrm{mg} / \mathrm{L}$ 之间, 均值为 $2.04 \mathrm{mg} / \mathrm{L}$, 略高于 I 类水标准, 无明显季节波动规律. 空间上, 各水 质参数无显著差异,变化趋势基本一致. 仅 TP 和 Chl.a 浓度出现上游、湖心、取水口递减的趋势.

表 1 横山水库主要水质参数

Tab.1 Main water quality indexes in Hengshan Reservoir

\begin{tabular}{|c|c|c|c|c|c|c|c|c|c|}
\hline 日期 & 点位 & $\begin{array}{c}\mathrm{TN} / \\
(\mathrm{mg} / \mathrm{L})\end{array}$ & $\begin{array}{c}\text { DTN/ } \\
(\mathrm{mg} / \mathrm{L})\end{array}$ & $\begin{array}{c}\mathrm{TP} / \\
(\mathrm{mg} / \mathrm{L})\end{array}$ & $\begin{array}{c}\text { DTP/ } \\
(\mathrm{mg} / \mathrm{L})\end{array}$ & $\begin{array}{c}\text { SRP/ } \\
(\mu g / L)\end{array}$ & $\begin{array}{l}\text { WT/ } \\
{ }^{\circ} \mathrm{C}\end{array}$ & $\begin{array}{c}\mathrm{DO} / \\
(\mathrm{mg} / \mathrm{L})\end{array}$ & $\begin{array}{l}\text { Chl.a/ } \\
(\mu \mathrm{g} / \mathrm{L})\end{array}$ \\
\hline $2014-06-19$ & L1 & $1.31 \pm 0.06$ & $1.09 \pm 0.11$ & $0.023 \pm 0.003$ & $0.006 \pm 0.003$ & $4.3 \pm 1.5$ & 26.9 & 0.28 & 28.5 \\
\hline $2014-06-15$ & $\mathrm{~L} 2$ & 1.55 & 1.06 & 0.035 & 0.010 & 1.9 & 25.9 & 0.19 & 28.1 \\
\hline $2014-06-15$ & L3 & 0.90 & 0.43 & 0.049 & 0.010 & 7.2 & 27.9 & 11.1 & 27.1 \\
\hline $2014-06-15$ & L4 & 1.48 & 0.71 & 0.093 & 0.016 & 3.9 & 24.4 & 8.1 & 46.8 \\
\hline $2014-06-15$ & $\mathrm{R} 1$ & 1.40 & 0.83 & 0.033 & 0.007 & 13.3 & 25.3 & 11.5 & 6.3 \\
\hline $2014-06-15$ & $\mathrm{R} 2$ & 0.46 & 0.35 & 0.025 & 0.009 & 24.9 & 26.8 & 5.8 & 3.4 \\
\hline $2015-04-23$ & 平均值 & $2.51 \pm 0.04$ & $2.32 \pm 0.13$ & $0.061 \pm 0.007$ & $0.039 \pm 0.032$ & $1.1 \pm 0.2$ & $18.1 \pm 0.8$ & $8.14 \pm 1.12$ & $5.1 \pm 0.6$ \\
\hline $2015-05-05$ & 平均值 & $2.53 \pm 0.09$ & $2.42 \pm 0.07$ & $0.025 \pm 0.008$ & $0.010 \pm 0.005$ & $0.6 \pm 0.1$ & $21.0 \pm 0.1$ & $5.45 \pm 0.85$ & $3.1 \pm 1.3$ \\
\hline $2015-05-19$ & 平均值 & $2.58 \pm 0.14$ & $2.39 \pm 0.12$ & $0.041 \pm 0.008$ & $0.021 \pm 0.007$ & $3.5 \pm 1.4$ & $22.6 \pm 0.1$ & $5.45 \pm 3.22$ & $8.2 \pm 4.8$ \\
\hline $2015-06-04$ & 平均值 & $2.36 \pm 0.09$ & $2.42 \pm 0.04$ & $0.020 \pm 0.006$ & $0.007 \pm 0.003$ & $2.4 \pm 0.6$ & 23.8 & - & $4.5 \pm 2.0$ \\
\hline $2015-06-18$ & 平均值 & $2.37 \pm 0.17$ & $2.21 \pm 0.13$ & $0.039 \pm 0.011$ & $0.016 \pm 0.004$ & $3.4 \pm 1.8$ & $24.8 \pm 0.3$ & $2.89 \pm 4.35$ & $4.9 \pm 1.2$ \\
\hline $2015-07-01$ & 平均值 & $2.21 \pm 0.08$ & $2.14 \pm 0.07$ & $0.027 \pm 0.005$ & $0.016 \pm 0.004$ & $2.5 \pm 1.0$ & $26.3 \pm 0.3$ & $0.44 \pm 0.16$ & $6.2 \pm 5.7$ \\
\hline $2015-07-14$ & 平均值 & $2.33 \pm 0.13$ & $2.18 \pm 0.07$ & $0.035 \pm 0.010$ & $0.019 \pm 0.009$ & $3.1 \pm 1.0$ & $27.6 \pm 1.0$ & $5.12 \pm 4.14$ & $13.2 \pm 9.7$ \\
\hline $2015-07-29$ & 平均值 & $2.11 \pm 0.07$ & $2.03 \pm 0.06$ & $0.021 \pm 0.004$ & $0.012 \pm 0.002$ & $0.6 \pm 0.3$ & $30.8 \pm 0.3$ & $1.21 \pm 0.21$ & $4.8 \pm 1.3$ \\
\hline $2015-08-12$ & 平均值 & $2.03 \pm 0.07$ & $1.61 \pm 0.08$ & $0.027 \pm 0.002$ & $0.021 \pm 0.004$ & $1.0 \pm 0.3$ & $29.3 \pm 0.4$ & $0.53 \pm 0.12$ & $8.3 \pm 2.5$ \\
\hline $2015-08-27$ & 平均值 & $1.78 \pm 0.03$ & $1.58 \pm 0.03$ & $0.018 \pm 0.003$ & $0.003 \pm 0.001$ & $2.3 \pm 0.8$ & $29.5 \pm 0.4$ & $3.71 \pm 2.68$ & $17.3 \pm 3.1$ \\
\hline $2015-09-25$ & 平均值 & $1.54 \pm 0.07$ & $1.22 \pm 0.03$ & $0.030 \pm 0.004$ & $0.009 \pm 0.002$ & $1.8 \pm 1.0$ & $25.3 \pm 0.2$ & $4.52 \pm 1.92$ & $31.7 \pm 5.2$ \\
\hline $2015-10-26$ & 平均值 & $1.31 \pm 0.27$ & $0.98 \pm 0.01$ & $0.038 \pm 0.011$ & $0.016 \pm 0.002$ & $3.0 \pm 1.9$ & $23.3 \pm 0.4$ & $6.27 \pm 1.62$ & $15.2 \pm 2.5$ \\
\hline
\end{tabular}

横山水库 SD 总体处于较高水平,除 6 月 18 日和 9 月 25 日外,均高于 $1.5 \mathrm{~m}$,并在 7 月 29 日达到监测期 最高值 $3.15 \mathrm{~m}$ (图 3). SS 的波动较为频繁且幅度较大, 春末夏初阶段 (5-6 月) 曾出现两个明显的波峰, 夏 季 (7-8 月) 则处于较低水平, 且无明显波动, 而秋季出现另一个峰值 (图 3). SS 与 SD 整体上表现出相反的 变化趋势, 说明 SS 是影响 SD 的主要因素之一. 但是 SS 在 9 月底的峰值明显低于 6 月 18 日而两个时期 SD 
处于同一低水平, 说明秋季 SD 还受浮游植物生物量升高的影响.

横山水库 $T L I$ 指数介于 $36 \sim 48$ 之间, 为中营养水体 $(30 \leqslant T L I \leqslant 50)$, 最高值为 9 月 25 日的 47.6(图 3), 仅在该时期的上游区 $T L I$ 达到富营养水平 $(T L I=50.3)$. $T L I$ 指数与 SS 总体上具有同步变化趋势, 且二者呈 正相关.

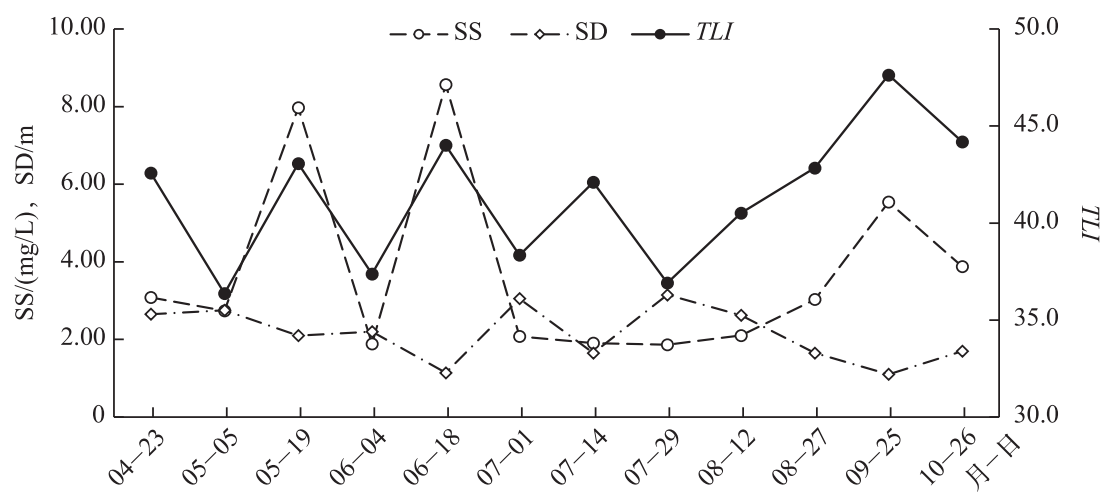

图 3 横山水库 SS、SD、TLI 平均值的变化

Fig.3 Variations of average SS, SD, TLI values in Hengshan Reservoir

\section{3 底质状况}

横山水库底泥的表层 $20 \mathrm{~cm}$ 表现出相对较高的有机质含量和氮、磷含量. 坝前 L1 样点采集深 $55 \mathrm{~cm}$ 的 泥柱, 其 TOC、TN、TP 含量总体上随深度增加而下降, 表层 $20 \mathrm{~cm}$ 深度偏高, 平均值分别为 $25.85 \mathrm{~g} / \mathrm{kg}$ 、3499 $\mathrm{mg} / \mathrm{kg} 、 655 \mathrm{mg} / \mathrm{kg}$ (图 4). 此外, L5、L4 两个样点分别采集了 $11 \mathrm{~cm}$ 和 $36 \mathrm{~cm}$ 深的泥柱, 其碳、氮、磷含量均较 水深最大的 L1 点低, 表层 TOC、TN、TP 含量分别为 $24.79 \mathrm{~g} / \mathrm{kg} 、 3238 \mathrm{mg} / \mathrm{kg} 、 534 \mathrm{mg} / \mathrm{kg}$ 和 $22.44 \mathrm{~g} / \mathrm{kg}$ 、2213 $\mathrm{mg} / \mathrm{kg} 、 374 \mathrm{mg} / \mathrm{kg}$. 横山水库底泥中营养盐含量总体上与相邻水库天目湖沙河水库的含量相当 ${ }^{[23]}$, 表层 20 $\mathrm{cm}$ 的有机质和氮有一定的污染, TP 含量不高.

$\mathrm{TOC} /(\mathrm{g} / \mathrm{kg})$

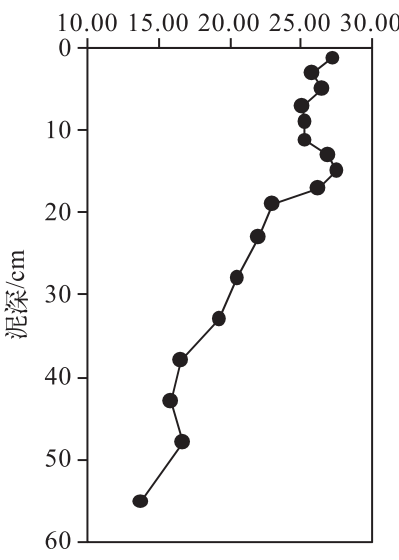

$\mathrm{TN} /(\mathrm{mg} / \mathrm{kg})$

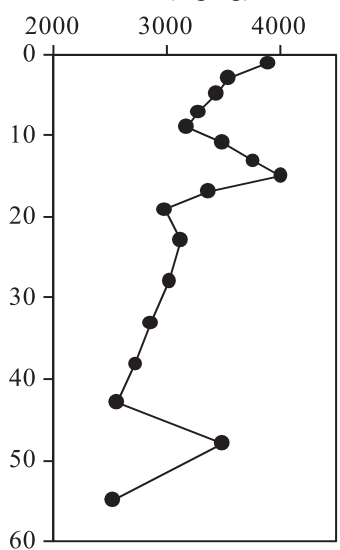

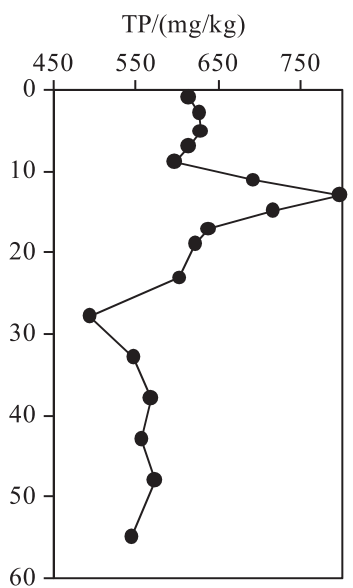

图 4 横山水库坝前 L1 样点底泥有机碳、总氮、总磷含量剖面分布

Fig.4 Vertical distribution of organic carbon, total nitrogen and total phosphorus contents in L1 site of Hengshan Reservoir

\section{4 浮游植物状况}

2.4 .1 时间变化 2014 年 6 月横山水库水色较差期间, 坝前 L1 样点表、中、底层浮游植物总生物量分别为 
$19.114 、 15.485$ 和 $13.508 \mathrm{mg} / \mathrm{L}$, 其中硅藻门的生物量分别为 $12.768 、 10.222$ 和 $9.528 \mathrm{mg} / \mathrm{L}$, 平均占浮游植物 总生物量的 $68 \%$. 2015 年, 横山水库的 3 个样点平均浮游植物总生物量在时间上变化很大: $4-8$ 月生物量 均低于 $8 \mathrm{mg} / \mathrm{L}$, 且 7 月前无明显变化, 7-8 月平缓上升, $9-10$ 月则显著升高 $(>10 \mathrm{mg} / \mathrm{L})$, 特别是 9 月, 生物 量达到 $20.95 \mathrm{mg} / \mathrm{L}$ ( 图 5) , 水色发褐,与 2014 年 6 月的情形相似,已经达到水华水平.

硅藻为横山水库中浮游植物生物量的主要贡献者,平均生物量占浮游植物总生物量的 $52 \%, 9$ 月的浮游 植物峰值也因硅藻生物量猛增所致. 是第二优势门类一一隐藻的数倍. 硅藻生物量在 $4 、 6$ 月分别出现小峰 值, 7-9 月则不断上升, 且 9 月陡增, 达到监测期的最大值. 其余门类, 隐藻、绿藻、蓝藻、甲藻、裸藻、金藻生 物量占浮游植物总生物量的平均值分别为 $18 \% 、 12 \% 、 10 \% 、 5 \% 、 3 \% 、 0.3 \%$. 蓝藻生物量仅在 7一 10 月占比为 9\% 17\% , 而 5-7 月中旬, 隐藻生物量平均占浮游植物总生物量的 $27 \%$, 介于 $18 \% \sim 43 \%$ 之间. 绿藻在生物 量监测期一直保持较低水平, 与蓝藻的变化趋势基本一致( 图 5 ).

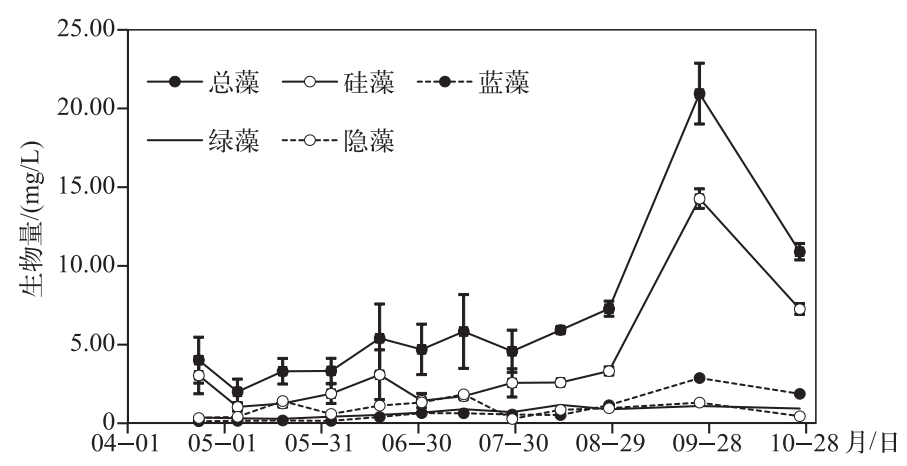

图 52015 年 4-10 月横山水库浮游植物及主要优势门的生物量变化

Fig.5 Variation of biomass of total phytoplankton and the main phyta in Hengshan Reservoir from April to October, 2015

细胞丰度上, 蓝藻 > 绿藻 > 硅藻. 特别是蓝藻, 细胞丰度远高于其他藻类, 但由于细胞体积小, 生物量上远 低于硅藻. 此外, 蓝藻细胞丰度自 7 月起明显增加. 硅藻细胞丰度则大部分时期均达到 $10^{6} \sim 10^{7}$ cells $/ \mathrm{L}$, 达到 轻度硅藻水华水平 ${ }^{[24]}$. 另一方面, 硅藻夏季细胞丰度相比春季稍有回落, 但与 2010-2011 年相比, 夏季硅澡 丰度仍有大幅增加 ${ }^{[14]}$.

2.4 .2 空间变化 从 2014 年 6 月各个点位浮游植物各门生物量可以看出, 人湖河道的藻类生物量显著低于 水库 (图 6a). 这说明藻类主要在水库中生长, 而人湖河道由于水浅、底栖藻多、水草多等因素, 浮游植物生 物量并不高, 水库中相对静止、低浊度的水体更适合浮游植物生长. 就水库中不同点位的差别来看, 靠近人 湖河口区的浮游植物生物量总体上偏高,但总的差别不大 (图 6).

2.4 .3 硅藻种群结构 从硅藻的组成上看, 横山水库共检出小环藻属 (Cyclotella)、针杆藻属 (Synedra)、曲壳 藻属 (Achnanthes)、直链藻属 (Melosira)、桥穹藻属 (Cymbella)、舟形藻属 (Navicula) 和异壳藻属 (Cocconeis) 7 个属. 其中生物量上以小环藻、针杆藻、曲壳藻和直链藻为主, 占硅藻总生物量的 $90 \%$ 以上.

不同时期的优势种不同, 春季及夏初小环藻属为高优势度藻属, 但优势度总体上不断下降, 而针杆藻的 优势度不断上升. 就生物量而言, 时间上, 针杆藻仅在 5 月 5 日比小环藻略低, 其他时期针杆藻的生物量均 高于小环藻. 空间上, 二者生物量差别在上游区最为明显, 其次是湖心, 再次是取水口. 曲壳藻的优势度始终 较低, 仅在 4 月至 5 月初处于优势或接近优势水平. 直链藻的优势度波动较大, 在 5 月中旬和 7 月中旬均出 现了明显的峰值, 优势度达到了 0.05 以上, 10 月下旬又出现了优势度较高的情况 (图 7 ).

\section{3 讨论}

\section{1 水质因子与硅藻的关系}

TN 、TP 作为水体的主要营养组分, 通常能够决定浮游植物的生物量 ${ }^{[12]}$. 然而有研究表明, 相比温带地 

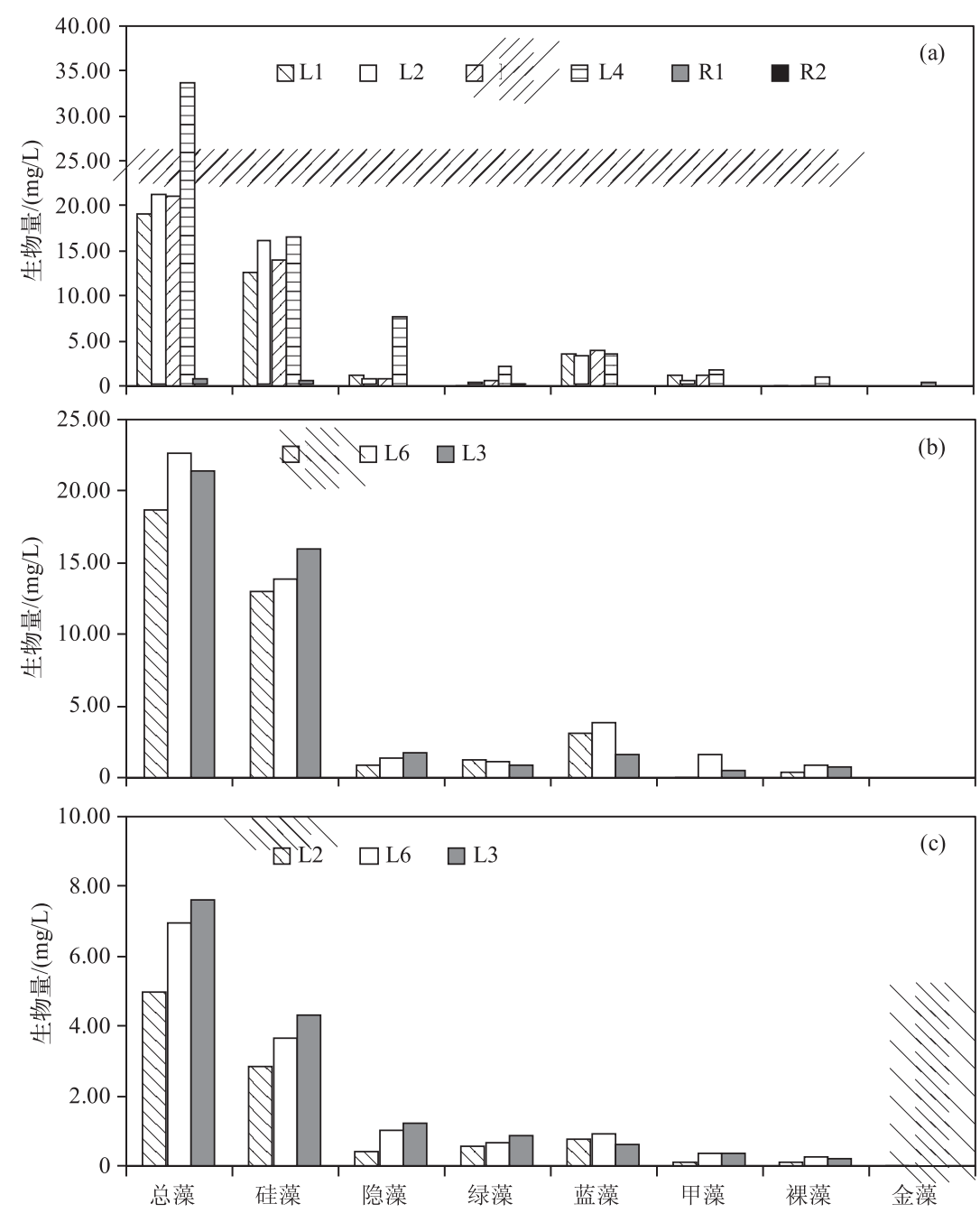

图 6 水库中不同点位浮游植物生物量的差别:

（a）2014 年 6 月硅藻水华期; (b) 2015 年 9 月硅藻水华期; (c) 2015 年总体平均值

Fig.6 Spatial difference of phytoplankton biomass in Hengshan Reservoir :

(a) June of 2014; (b) September of 2015; (c) 2015

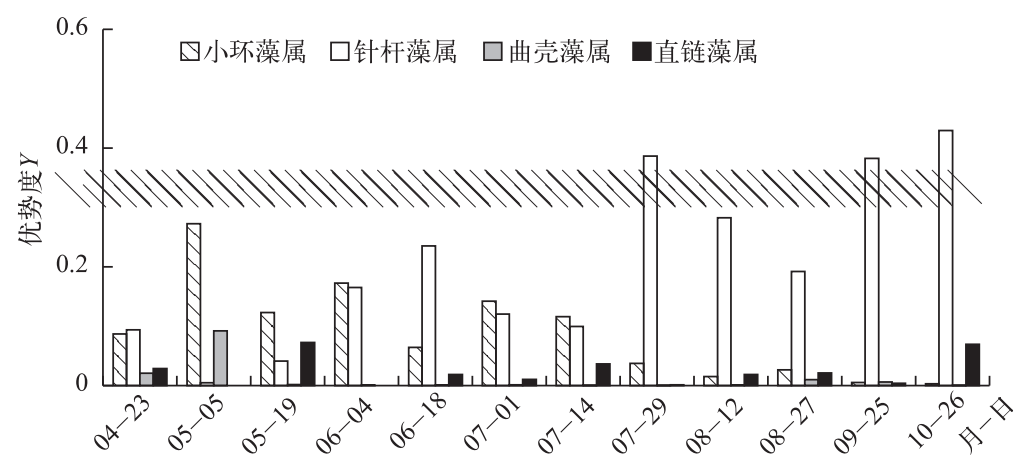

图 7 横山水库硅藻主要属的优势度变化

Fig.7 Variations of dominance degree of the major diatom genus in Hengshan Reservoir 
区, 热带和亚热带地区湖泊中 TN、TP 浓度与 Chl.a 浓度的关系较弱 ${ }^{[25]}$. 在本研究中, 主要营养盐浓度与藻类 生物量甚至呈负相关 (表 2).

营养盐之间的相关性分析表明, TN 浓度与 DTN 浓度高度相关 $\left(R^{2}>0.9\right)$, TP 浓度与 DTP 浓度也高度相 关. TN、DTN 浓度与针杆藻生物量 $\left(\mathrm{BM}_{\mathrm{syn}}\right)$ 、硅藻生物量 $\left(\mathrm{BM}_{\mathrm{bac}}\right)$ 、蓝藻生物量 $\left(\mathrm{BM}_{\mathrm{cyano}}\right)$ 、总藻生物量 $\left(\mathrm{BM}_{\mathrm{phyto}}\right)$ 以及 Chl.a 浓度均呈现较高的负相关关系 (表 2). 而 TP、DTP 浓度与浮游植物生物量相关性不显著.

表 2 横山水库主要水质因子与各生物因子之间的相关关系

Tab.2 Correlations between major water quality and biological indexes in Hengshan Reservoir

\begin{tabular}{cccccc}
\hline 水质因子 & $\mathrm{BM}_{\text {syn }}$ & $\mathrm{BM}_{\text {bac }}$ & $\mathrm{BM}_{\text {cyano }}$ & $\mathrm{BM}_{\text {phyto }}$ & Chl.a \\
\hline TN & $-0.728^{* * *}$ & $-0.711^{* *}$ & $-0.711^{* *}$ & $-0.725^{* *}$ & $-0.746^{* * *}$ \\
DTN & $-0.761^{* *}$ & $-0.748^{* *}$ & $-0.718^{* *}$ & $-0.767^{* *}$ & $-0.789^{* *}$ \\
TP & -0.003 & $0.044^{* *}$ & -0.121 & -0.012 & -0.085 \\
DTP & -0.216 & -0.182 & -0.290 & -0.197 & -0.239 \\
\hline
\end{tabular}

** 表示 $P<0.001$.

相关关系并不一定是因果关系: 横山水库水体 TN 浓度与硅藻生物量的负相关不能理解为水体 TN 浓度 越高, 硅藻生物量就越低. TN 浓度与硅藻生物量呈反比, 主要是因为受 TN 外源供给的影响, 观测期 TN 浓度 处于下降阶段: 春季 TN 浓度较高, 夏、秋季浓度降低; 与此同时, 温度却处于上升阶段, 从季节演替看, 硅藻 的生长率主要受温度的控制, 氮的影响处于次要地位. 另外, 当 $\mathrm{TN}>1.0 \mathrm{mg} / \mathrm{L}$ 时, 对于硅藻生长而言, $\mathrm{TN}$ 处 于相对饱和状态, 其变化对硅藻生长的影响不大 ${ }^{[26]}$. 从 TN: TP 比看, 调查期也处于 $38 \sim 153$ 之间, 难以出现 $\mathrm{N}$ 限制的情况 ${ }^{[27]}$. 由图 8 可知, 当硅藻生物量的最高值出现时, TN、TP 浓度均处于较低水平. 可见, 该水库 现阶段的营养水平仍可为硅藻大量增殖提供足够的营养物质. TN 浓度不是硅藻生物量的限制因素, 甚至 $\mathrm{TN} 、 \mathrm{TP}$ 浓度均不是横山水库 2015 年硅藻生物量大幅波动的主要影响因素.
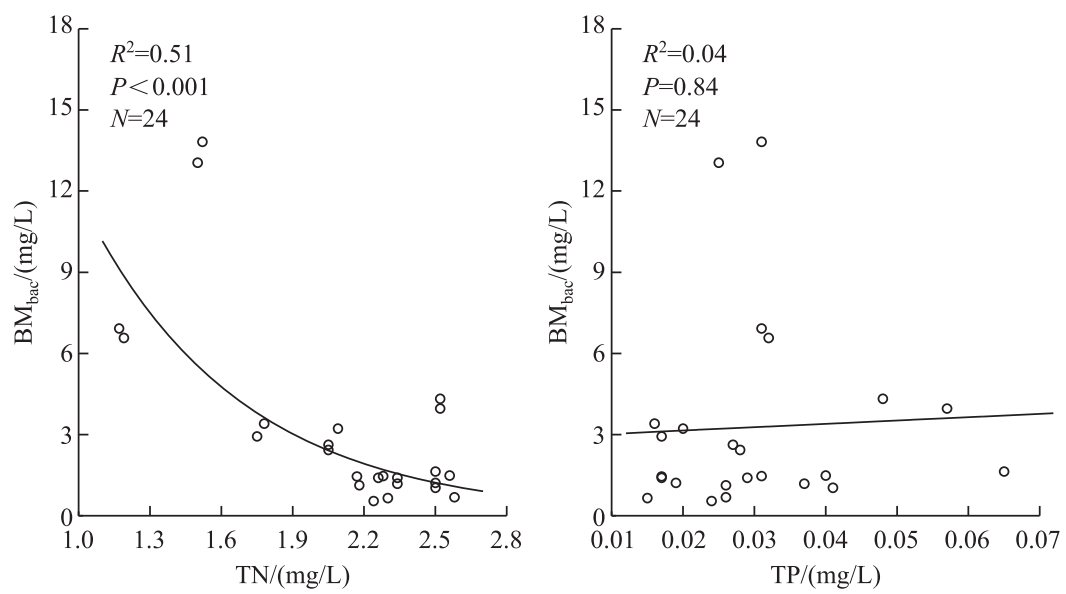

图 8 硅藻生物量与营养盐的关系

Fig.8 Relations between diatom biomass and nutrients

由于横山水库调查期间硅藻以针杆藻为主, 因此针杆藻生物量和上述水质因子的相关关系与图 8 基本 一致, 而小环藻生物量却与 TP 浓度呈显著正相关 (图 9, $P<0.05$ ), 相比针杆藻而言, 小环藻在硅藻中为细胞 较小的藻属, 可能对 TP 浓度更加敏感 ${ }^{[28]}$. 因此在现有的营养水平下, 其生物量的变化与 TP 浓度相关度更 高. 这表明, 控制 TP 浓度可能可以作为限制硅藻异常增殖的手段之一.

光照条件是影响藻类生长的另一个重要因素 ${ }^{[29]}$. 但在横山水库, $\mathrm{SD}$ 始终保持较高水平, 仅在硅藻生物 量出现峰值时稍有下降, 并且峰值期 (9 月) 相比于 7-8 月的光照条件并无优势, 因此无法认定光照条件是 


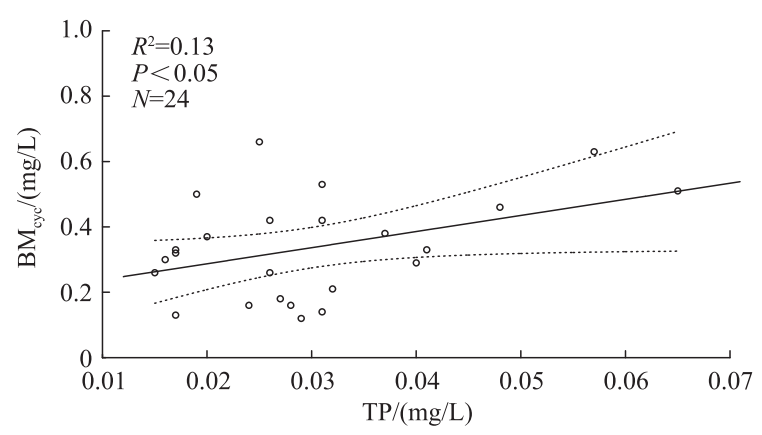

图 9 小环藻生物量与 $\mathrm{TP}$ 浓度的关系及 其 95\% 置信区间

Fig.9 Relation between Cyclotella biomass and TP concentration and its $95 \%$ confidence interval
引起该水库硅藻异常增殖的原因, 而是藻类的 异常增殖引起水体感官效果变差, 影响水下 光强.

\section{2 换水率对水质和硅藻的影响}

相比于自然湖泊而言, 水库可以人为调节 水体换水率. 横山水库始终保持大致稳定的水 位, 即随着上游水体和降雨的输人, 水库采取及 时排水的管理方式. 上游来水带来的泥沙、溶解 性营养盐和生物体的变化等, 可能会影响水库 的整体水质 ${ }^{[30-31]}$.

$\mathrm{TN}$ 浓度与换水率呈正比 (图 10a). TN 浓 度和 $W R_{15}$ 在总体上符合线性正相关关系, 仅 4 月 23 日和 5 月 5 日两个监测期的数据明显偏 离了二者的关系, 可能是由于春季农业活动频 繁, 导致该时期水库的营养本底值较高, 在换水

率较低时依然保持较高的 TN 浓度 ${ }^{[32]}$.

由 $W R_{15}$ 的定义可知, 若某一时期该地区的降雨量增加, 则 $W R_{15}$ 将会变大. 因此, $\mathrm{TN}$ 浓度与 $W R_{15}$ 的正相关 关系说明水库 TN 浓度很大程度上受雨水带来的外源输人控制. 雨水的面源效应因季节不同、流域农业活动不 同、水库水情不同而不同: 春季至春夏之交,太湖流域农业活动频繁, 降雨冲刷导致上游来水 $\mathrm{TN}$ 浓度较高,较 高的换水率将导致库体 TN 浓度升高; 夏、秋季节, 农事活动下降, 流域植被改善, 对营养盐的截留能力增强, 雨 水增大, 则会对水库 $\mathrm{TN}$ 起到稀释作用 ${ }^{[33]}$; 但径流后期, 随着壤中流的比例增大, 径流中氮浓度又会出现一定 程度的上升 ${ }^{[34]}$. 因此水库 TN 浓度自 5 月 19 日达到峰值后呈现出下降的趋势, 并且与换水率呈正比. 然而, 较 高的换水率不利于浮游植物包括硅藻生物量的积累, 表现出 TN 浓度与硅藻生物量的负相关关系.

水库磷主要来源于上游河流、地表径流、生产生活污染、养殖投放、大气沉降等外源和内源的沉积物释 放 ${ }^{[35]}$. SRP 浓度与 $W R_{15}$ 表现出显著的正相关关系(图 10b), 并且 TP、DTP 浓度与 $W R_{15}$ 也存在相似的关系. 另外, 底层溶解氧数据表明, TP、DTP、SRP 浓度与溶解氧浓度的关系并不明显, 表明底泥磷释放对该水库中 磷浓度的贡献度较小. 因此, 横山水库的营养盐浓度受外源输人的影响明显, 这也可以解释 TP 浓度波动频 繁且幅度大的现象.
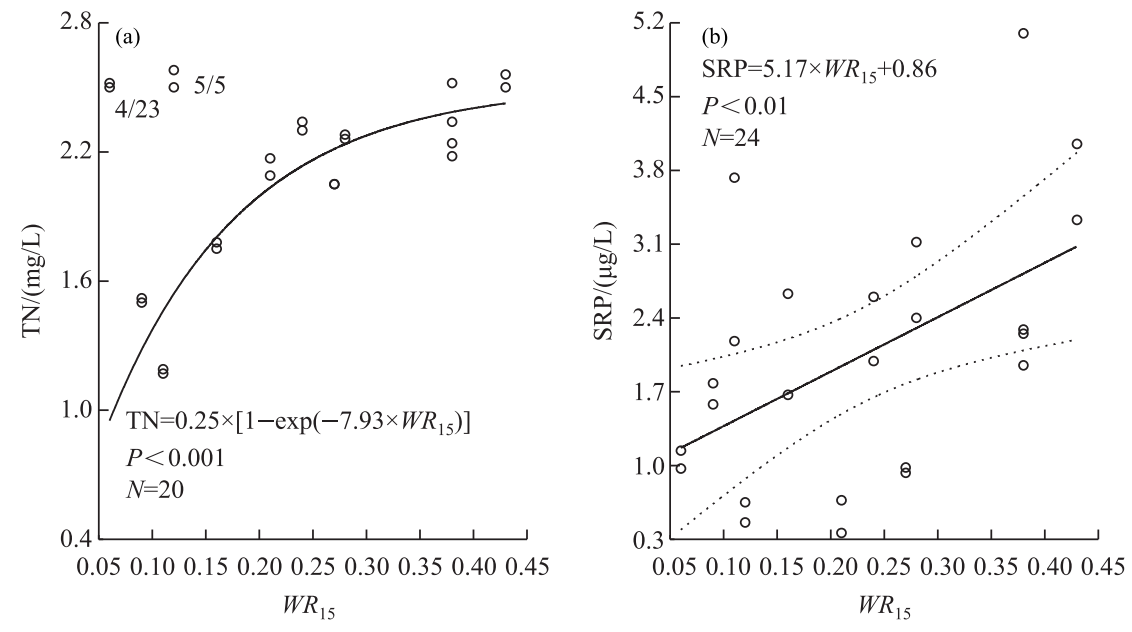

图 10 横山水库 $\mathrm{TN}(\mathrm{a}) 、 \operatorname{SRP}(\mathrm{b})$ 浓度与 $W R_{15}$ 的关系

Fig.10 Relations between $W R_{15}$ and $\operatorname{TN}(\mathrm{a}), \operatorname{SRP}(\mathrm{b})$ concentrations in Hengshan Reservoir 
通过蓄排水可以调节水深, 且水库排水具有冲刷作用, 能够排出水体中的浮游植物、氮磷营养盐乃至浮 游动物 ${ }^{[12]}$. 横山水库硅藻生物量与 $W R_{15}$ 表现出显著的负相关关系 (图 11). 高换水率一方面有利于硅藻的 生长、减少沉降, 在该水库处于中营养水平的情况下, 有利于保持硅藻在浮游植物群落中的优势地位, 因此 在夏季高温时, 尽管蓝藻密度显著上升, 但生物量始终保持在低位; 另一方面, 较高的换水率又不利于硅藻 生物量在水库中的积累, 如在经历夏季高换水率后, 由于降水量减少, 9 月底横山水库的换水率降为 0.09 , 随 之出现硅藻生物量的最高值, 且针杆藻等硅藻的单个体积比前期低生物量时明显增大, 说明低换水率为硅 藻提供了较为稳定的生长环境. 此外, 高换水率可能引起生长期较长的大型浮游动物枝角类、桡足类生物量 的减少和生长期较短的小型浮游动物轮虫类生物量的上升, 导致浮游动物对浮游植物生物量的控制作用减 弱 ${ }^{[36]}$. 水库排水的冲刷作用不仅对硅藻有效, 蓝藻同样会受到影响, 在水体中的生物量随之降低 ${ }^{[37]}$. 有研究 表明,通过在不同季节保持一定的排水量, 可以抑制水库藻类异常增殖的强度 ${ }^{[38]}$.

\section{3 水文、水质的共同作用}

尽管水库排水的冲刷对硅藻生物量的控制作用明显, 却不是影响硅藻生物量的唯一因素. 一方面, 当水 力停留时间延长至一定水平时, 水体的稳定性会逐渐恢复, 进而营养盐将再次成为左右硅藻异常增殖的主 要因素之一. 另一方面, 即便在低水力停留时间、高换水率的情况下, 营养盐浓度的高低对硅藻同样能够产 生作用, 如在平均水力停留时间约为 $10 \mathrm{~d}$ 的竹仙洞水库, 营养盐水平仍可以影响浮游植物的丰度 ${ }^{[20]}$. 另外, Tolotti 等 ${ }^{[39]}$ 在比较两个不同水力停留时间的水库 $\mathrm{S}$ 和 $\mathrm{T}$ 时发现, 尽管 $\mathrm{S}$ 水库平均水力停留时间 $(43 \mathrm{~d})$ 长于 $\mathrm{T}$ 水库 $(8 \mathrm{~d})$, 但营养盐水平低于 $\mathrm{T}$ 水库, 从而导致 $\mathrm{T}$ 水库的叶绿素浓度和浮游植物丰度高于 $\mathrm{S}$ 水库, 说明水 力停留时间和营养盐对藻类共同作用. 在横山水库, 同样出现二者共同作用影响藻类生物量的情况.

结合温度 $\left(A T_{10} 、 \mathrm{WT}\right) 、 \mathrm{TP} 、 W R_{15}$, 通过多元线性回归分析得到硅藻生物量方程:

$$
\mathrm{BM}_{\text {bac }}=3.41 \mathrm{e}^{-8.42 \times W R_{15}+63.94 \times \mathrm{TP}}
$$

方程中各参数均处于显著水平 $(P<0.001)$. 该分析显示, WT 或 $A T_{10}$ 均处于非显著水平 $(P>0.05)$, 表明 温度对硅藻生物量的影响可能是阈值性的, 即低于某一温度时, 硅藻的生长速率较低 ${ }^{[40]}$. 利用该拟合公式 获得的硅藻生物量 $\left(\mathrm{BM}_{\mathrm{sim}}\right)$ 与实测硅藻生物量 $\left(\mathrm{BM}_{\mathrm{bac}}\right)$ 进行拟合, 结果表明拟合度较高 $\left(R^{2}=0.85\right.$, 图 12), 能 够地较好描述横山水库 2015 年硅藻生物量随 $W R_{15}$ 和 TP 浓度的变化情况.

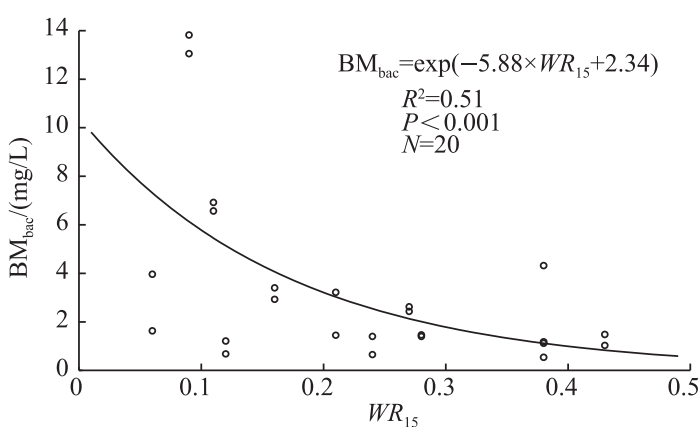

图 11 横山水库硅藻生物量与 $W R_{15}$ 的关系

Fig.11 Relation between diatom biomass and $W R_{15}$ in Hengshan Reservoir

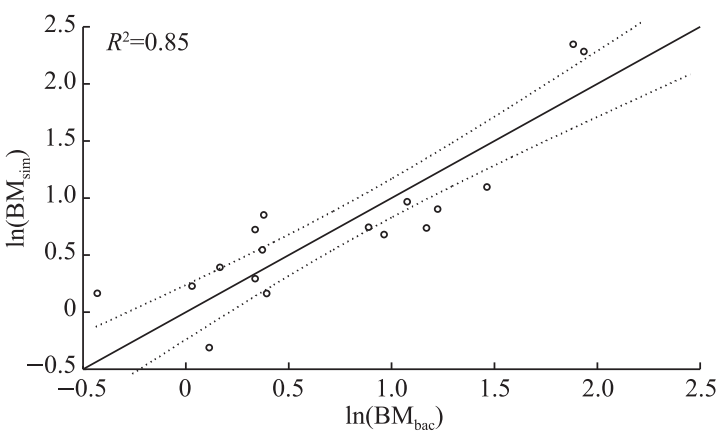

图 12 硅藻实测生物量与方程拟合生物量的拟合关系

Fig.12 Relation between measured diatom biomass and simulated diatom biomass

\section{4 结论}

1 ) 横山水库总体上处于中营养水平, 营养盐浓度与硅藻及其他门浮游植物生物量之间的相关性并不 好, 仅 TP 浓度与小环藻生物量显示出较显著的正相关关系. 温度对硅藻生长的影响可能是阈值性的, 温度 较低时产生抑制作用,夏季温度较高时可能对硅藻生长也产生不利影响,但总体线性关系不好.

2) 横山水库的水体营养盐浓度本身同时受换水率和硅藻异常增殖影响, 氮、磷浓度均与换水率呈正比, 
透明度既受暴雨带来的无机颗粒物影响,也受浮游植物生物量影响.

3) 中营养状态水库的硅藻水华防控, 既要实施严格的营养盐外源控制, 也应考虑水力调控技术. 在硅藻 适宜生长的季节,保持一定的换水率能够有效防控硅藻生物量过度积累造成的水质风险.

\section{5 参考文献}

[ 1 ] Su Yuping, Lai Shouhui, Lin Jia et al. Research on the limiting nutrient in Shanzi Research, an eutrophic drinking water source. Acta Scientiae Circumstantiae, 2015, 35(10): 3107-3113. [苏玉萍, 赖寿辉, 林佳等. 富营养化饮用水源地山 仔水库限制性营养元素研究. 环境科学学报, 2015, 35(10): 3107-3113.]

[ 2 ] Li Chongwei, Hu Jie, Wang Sa et al. The source-sink landscape pattern change and its effect on phosphorus pollution in Yuqiao watershed. Acta Ecologica Sinica, 2012, 32(8): 2430-2438. [李崇巍, 胡婕, 王飒等. 流域“源-汇” 景观格局 变化及其对磷污染负荷的影响—— 以津于桥水库流域为例. 生态学报, 2012, 32(8): 2430-2438.]

[ 3 ] Lu Guihua, Zhang Jianhua. Present status and problems of comprehensive treatment of water environment in Taihu Lake and countermeasures. Water Resources Protection, 2014, 30(2) : 67-69. [陆桂华, 张建华. 太湖水环境综合治理的现 状、问题及对策. 水资源保护, 2014, 30(2): 67-69.]

[ 4 ] Qin B, Zhu G, Zhang Y et al. A drinking water crisis in Lake Taihu, China: Linkage to climatic variability and lake management. Environmental Management, 2010, 45(1) : 105-112.

[ 5 ] Zhu G, Cui Y, Han X et al. Response of phytoplankton to nutrient reduction in Shahe Reservoir, Taihu catchment, China. Journal of Freshwater Ecology, 2015, 30(1): 41-58.

[ 6 ] Ren Jie, Zhou Tao, Zhu Guangwei et al. Community structure characteristics of diatom in reservoirs located in the south of Jiangsu Province, China and its control factors. Environmental Science, 2016, 37(5): 1742-1753. [任杰, 周涛, 朱广伟 等. 苏南水库硅藻群落结构特征及其控制因素. 环境科学, 2016, 37(5): 1742-1753.]

[ 7 ] Zhang Yunlin, Chen Weimin, Zhou Wanping et al. Ecological study on the phytoplankton in Lake Tianmu from 2001 to 2002. Transactions on Oceanology and Limnology, 2006, (2) : 31-37. [张运林, 陈伟民, 周万平等. 2001-2002 年天目 湖 (沙河水库) 浮游植物的生态学研究. 海洋湖沼通报, 2006, (2) : 31-37.]

[ 8 ] Ma C, Yu H. Phytoplankton community structure in reservoirs of different trophic status, Northeast China. Chinese Journal of Oceanology and Limnology, 2013, 31(3): 471-481.

[ 9 ] Zhong Jingjing, Liu Maosong, Wang Yu et al. Spatial correlation of major water quality indices between the lake and rivers in Taihu Lake Basin. Chinese Journal of Ecology, 2014, 33(8): 2176-2182. [钟晶晶, 刘茂松, 王玉等. 太湖流域河流 与湖泊间主要水质指标的空间关联特征. 生态学杂志, 2014, 33(8) : 2176-2182.]

[10] Bai Xiaohua. Nitrogen and phosphorus load analysis in different water bodies in intensive rainfall events in mountain areas of Taihu basin. Environmental Science Survey, 2009, 28(4): 71-74. [白晓华. 太湖山地强降雨事件中不同水体的氮 磷负荷分析. 环境科学导刊, 2009, 28(4): 71-74.]

[11] Valeriano-Riveros ME, Vilaclara G, Castillo-Sandoval FS et al. Phytoplankton composition changes during water level fluctuations in a high-altitude, tropical reservoir. Inland Waters, 2014, 4(3) : 337-348.

[12] Rangel LM, Silva LHS, Rosa P et al. Phytoplankton biomass is mainly controlled by hydrology and phosphorus concentrations in tropical hydroelectric reservoirs. Hydrobiologia, 2012, 693(1) : 13-28.

[13] Xie Fulin, Yu Tao. Current status and protection measures in water source area of Hengshan Reservoir. Journal of Hydro$e c o l o g y, 2009,30$ (5) : 136-139. [谢福林, 于涛. 横山水库水源地水质现状及保护对策. 水生态学杂志, 2009, 30 (5) : 136-139.]

[14] Wu Donghao, Xu Zhaoan, Wang Yu et al. Seasonal variation of phytoplankton community structure in Hengshan Reservoir. Journal of Hydroecology, 2012, 33(4) : 54-57. [ 吴东浩, 徐兆安, 王玉等. 横山水库浮游植物群落结构季节性变化 特征. 水生态学杂志, 2012, 33(4) : 54-57.]

[15] Xiao Jun, Zong Lianggang, Cao Dan et al. Research on distribution of soil nitrogen and phosphorus content under different types of land usage in Yixing. Chinese Journal of Soil Science, 2012, 43(2) : 347-352. [肖峻, 宗良纲, 曹丹等. 宜兴地 区不同利用方式下土壤氮, 磷含量分布特性研究. 土壤通报, 2012, 43(2)：347-352.]

[16] Cui Yang, Zhu Guangwei, Li Huiyun et al. Spatial and temporal distribution characteristics of water quality in Shahe Reservoir within Tianmuhu Reservoir and its relationship with phytoplankton community. Journal of Hydroecology, 2014,35 
(3) : 10-18. [崔扬, 朱广伟, 李慧帻等. 天目湖沙河水库水质时空分布特征及其与浮游植物群落的关系. 水生态 学杂志, 2014, 35(3) : 10-18.]

[17] Hu Hongjun, Wei Yinxin eds. The freshwater algae of China: Systematics, taxonomy and ecology. Beijing: Science Press, 2006. [胡鸿钧, 魏印心. 中国淡水藻类——系统、分类及生态. 北京: 科学出版社, 2006.]

[18] Sun Jun, Liu Dongyan, Qian Shuben. Study on phytoplankton biomass I. phytoplankton measurement biomass from cell volume or plasma volume. Acta Oceanologica Sinica, 1999, 21(2): 75-85. [孙军, 刘东艳, 钱树本. 浮游植物生物量 研究: I. 浮游植物生物量细胞体积转化法. 海洋学报, 1999, 21(2):75-85.]

[19] McNaughton S. Relationships among functional properties of Californian grassland. Nature, 1967, 216: 168-169.

[20] Hu Ren, Xiong Jiangxia, Han Boping. Structure and dynamics of phytoplankton assemblage in a small eutrophic reservoir with a short residence time. Ecology and Environment, 2008, 17(4): 1319-1326. [胡韧, 熊江霞, 韩博平. 具有短水力 滞留的小型富营养化水库浮游植物群落结构与动态. 生态环境, 2008, 17(4) : 1319-1326.]

[21] The R Development Core Team. R: A language and environment for statistical computing [EB/OL]. Vienna, Austria: R Foundation for Statistical Computing. https://www.R-project.org/, 2015-08-14.

[22] Wilkinson GN, Rogers CE. Symbolic descriptions of factorial models for analysis of variance. Applied Statistics, 1973,22 (3) : 392-399.

[23] He Ranran, Gao Yongxia, Wang Fang et al. Spatial-temporal distribution of nutrients and its causation in Tianmu Lake, China. Journal of Agro-Environment Science, 2009, 28(2) : 353-360. [贺申冉, 高永霞, 王芳等. 天目湖水体与沉积 物中营养盐时空分布及成因. 农业环境科学学报, 2009, 28(2):353-360.]

[24] Zheng Jianjun, Zhong Chenghua, Deng Chunguang. Discussion on definition of algal bloom. Water Resources Protection, 2006, 22 (5) : 45-47. [郑建军, 钟成华, 邓春光. 试论水华的定义. 水资源保护, 2006, 22(5): 45-47.]

[25] Soares MCS, Huszar VLM, Roland F. Phytoplankton dynamics in two tropical rivers with different degrees of human impact (Southeast Brazil). River Research and Applications, 2007, 23(7) : 698-714.

[26] Zhu Guangwei, Jin Yingwei, Ren Jie et al. Characteristics of diatom blooms in a reservoir-water supply area and the countermeasures in Taihu Basin, China. J Lake Sci, 2016, 28(1) : 9-21. DOI:10.18307/2016.0102. [朱广伟, 金颖薇, 任 杰等. 太湖流域水库型水源地硅藻水华发生特征及对策分析. 湖泊科学, 2016, 28(1) : 9-21.]

[27] Kosten S, Huszar VLM, Mazzeo N et al. Lake and watershed characteristics rather than climate influence nutrient limitation in shallow lakes. Ecological Applications, 2009, 19(7): 1791-1804.

[28] Saros JE, Anderson NJ. The ecology of the planktonic diatom Cyclotella and its implications for global environmental change studies. Biological Reviews, 2015, 90(2) : 522-541.

[29] Becker V, Caputo L, Ordóñez J et al. Driving factors of the phytoplankton functional groups in a deep Mediterranean reservoir. Water Research, 2010, 44(11) : 3345-3354.

[30] Huang Tinglin, Qin Changhai, Li Xuan. Studies on seasonal variation and sources of nitrogen and phosphorus in a canyon reservoir used as water source. Environmental Science, 2013, 34(9) : 3423-3429. [黄廷林, 秦昌海, 李璇. 峡谷型水源 水库的氮、磷季节变化及其来源分析. 环境科学, 2013, 34(9) : 3423-3429.]

[31] Guo Huaicheng, Xiang Nan, Zhou Feng et al. First flush effects of storm events of baoxiang river in Lake Dianchi watershed. Environmental Science, 2013, 34(4): 1298-1307. [郭怀成, 向男, 周丰等. 滇池流域宝象河暴雨径流初始冲 刷效应. 环境科学, 2013, 34(4): 1298-1307.]

[32] Zhu Guangwei. Spatial-temporal distribution pattern of water quality in Lake Taihu and its relation with cyanobacterial blooms. Resources and Environment in the Yangtze Basin, 2009, 18(5): 439-445. [ 朱广伟. 太湖水质的时空分异特征 及其与水华的关系. 长江流域资源与环境, 2009, 18(5): 439-445.]

[33] Wu Yali, Xu Hai, Yang Guijun et al. Progress in nitrogen pollution research in Lake Taihu. J Lake Sci, 2014, 26(1): 19-28. DOI: 10.18307/2014.0103. [ 吴雅丽, 许海, 杨桂军等. 太湖水体氮素污染状况研究进展. 湖泊科学, 2014, 26(1): 19-28.]

[34] Li Ruiling, Zhang Yongchun, Zeng Yuan et al. Effects of rainstorm on the export of farmland nitrogen with surface runoff in hilly area of Tai Lake basin. Journal of Agro-Environment Science, 2009, 28(6): 1185-1190. [李瑞玲, 张永春, 曾远 等. 太湖流域丘陵地区暴雨条件下农田氮素随地表径流迁移特征. 农业环境科学学报, 2009, 28(6): 1185-1190.]

[35] Shen Xiao, Li Xuyong, Zhang Wangshou. Research progress on phosphorus budgets and regulations in reservoirs. Chinese Journal of Applied Ecology, 2014, 25(12) : 3673-3682. [申校, 李叙勇, 张汪寿. 水库磷收支及其调控措施研究进 
展. 应用生态学报, 2014, 25(12): 3673-3682.]

[36] Silva LHS, Huszar VLM, Marinho MM et al. Drivers of phytoplankton, bacterioplankton, and zooplankton carbon biomass in tropical hydroelectric reservoirs. Limnologica-Ecology and Management of Inland Waters, 2014, 48: 1-10.

[37] Romo S, Soria J, Fernandez F et al. Water residence time and the dynamics of toxic cyanobacteria. Freshwater Biology, $2013, \mathbf{5 8}(3)$ : 513-522.

[38 ] Verspagen JMH, Passarge J, Jöhnk KD et al. Water management strategies against toxic Microcystis blooms in the Dutch delta. Ecological Applications, 2006, 16(1) : 313-327.

[39] Tolotti M, Boscaini A, Salmaso N. Comparative analysis of phytoplankton patterns in two modified lakes with contrasting hydrological features. Aquatic Sciences, 2010, 72(2) : 213-226.

[40] Ding Lei, Zhi Chongyuan. Environmental effects on diatom and its monitor of environment. Journal of Guizhou Normal University (Natural Sciences)，2006, 24(3) : 13-16. [丁蕾, 支崇远. 环境对硅藻的影响及硅藻对环境的监测. 贵州师 范大学学报 (自然科学版), 2006, 24(3): 13-16.] 